\title{
A Profile Analysis of the Customers of Islamic Banking in
}

\section{Peshawar, Pukhtunkhwa}

\author{
Dr. Syed Umar Farooq (Professor) \\ Kardan Institute of Higher Education, Kabul, Afghanistan \\ E-mail: syedumarfarooq5@hotmail.com \\ Ghayur Ahmad (Lecturer) \\ Islamia College University, Peshawar, Pakistan \\ Syed Hassan Jamil (Lecturer) \\ Kardan Institute of Higher Education, Kabul, Afghanistan
}

\begin{abstract}
The call of giving all subscribers a greater opportunity in the Islamic banking systems is well documented in the literature of the first decade of this millennium. Many banks and financial institutions across the world have attempted to implement programs aiming at increasing the customer's involvement in terms of investment and financing with varying degrees of success. The study describes the attributes and profiles of the Islamic banking subscribers.

A list of attributes and characteristics of the clientele having access to credit was developed from the current literature to augment the process of identifying and selecting Islamic banks for the study. The potential Islamic banks were nominated by the panel of proficient academicians. Four branches of Islamic banks having the maximum subscribers and highest number of attributes observed during the visits were selected for site visits. Interviews were conducted with borrowers to gain an insight into the diverse avenues of banking habits of subscribers. Findings of the study are examined in relation to religious inclination of the subscribers and allied socio-demographic factors. The empirical results suggest that the regulators of the Islamic banking should concentrate on the demography of a location when it comes to establishment of a new branch. Branches should be opened at those places where the prospective clientele are well-educated and inclined towards the Islamic principles in order to tap the potential market. The aspirations and preferences of the educated class shall be taken into consideration and products and services should be designed in such a way to cater to the needs of the subscribers. Implications for the generalizations of practice should be carefully considered and further research is suggested.
\end{abstract}

Keywords: Profile, Attributes, Islamic Banking System, Religion, Client satisfaction

\section{Introduction}

Since time immemorial religion guide the human beings towards attaining success in every sphere of life in this world and in the life thereafter. Islam is one of the greatest religions of the world and about 1.2 billion people are following this great religion. The Islamic Sharia regulations address all facets of life and the ultimate objective is to establish a just and equitable society for the mankind. One of the significant developments in the Muslim world during the last 50 years is the emergence of Islamic banking, which has appeared as a powerful movement. Although some attempts to reorganize banking activities along the Islamic lines go back to the early 1960's, the concept of Islamic banking is even older. In fact, the strong disapproval of interest by Islam and vital role of interest in the modern commercial banking system led Muslim thinkers to explore the ways and means to organize commercial banking on an interest free basis. However, for quite a long time, the idea of Islamic banking remained just a wishful thinking.

The Islamic banks endeavor to provide Sharia compliant products and services to the customers with the overall objective of attaining social and economic justice. Islam obviously, forbids exploitation in all its kinds and manifestations. In order to materialize this noble goal, it is important for Islamic banks to continuously undergo rigorous studies for analyzing the attributes of the customers profile in terms of their habits, behavior, perceptions and education. 
Interviews were conducted with borrowers of Islamic banks to gain an insight into the avenues of banking habits and attributes of subscribers of Islamic banks. Four months were spent interviewing, observing banking practices and studying the documents available at site.

\section{Literature review}

Solomon, (1996) states that whenever a client consumes a service or product this act is followed by some sentiment and attitude of the same client toward the same product or service in terms of satisfaction or dissatisfaction.

In this regard, Dispensa (1997) describes the salient attributes and characteristics of a satisfied client in terms of his repeated action of purchasing the same product or service and articulating positive communication to other prospective clients. On the contrary, a complete reversal of the state of affair will take place when a disgruntled client will speak very low about the product or service taken by him. In the ultimate conclusion, handsome amount of business will be lost in the process and a totally negative perception and image will be built in the market about the said service or product and it will bring harmful and disastrous effects in its wake for the company and business.

Gulledge (1996) describes this scenario as responsible for a shift of emphasis on measurement of the client's level of satisfaction for the use of products and services in diversified avenues. Many researchers like Bedal and Power (1993) and White (1994) has exerted handsome efforts in analyzing the level of client's satisfaction through the use of multiple criteria.

Bartell (1993) and Haron et al., (1994) have stated that the reason for this great emphasis is the fact that market forces faces a tug of war in terms of competition of the banking sector.

Vavra (1995) has identified the point that majority of the banks in public and private sectors faces stringent and stiff rivalries among themselves and banks management consider now onward the client satisfaction as a major point of concern and having broader marketing strategies being built around this single point.

Waterhouse and Morgan (1994) have identified the case of Lloyds Bank of the United Kingdom (UK) which was confronted with the problem of loosing instantly and tremendously the active clientele and hence loosing handsome business. The Lloyds Bank of UK therefore undergone a study to highlight the factors responsible for the dissatisfaction of the clientele and hence shift of their business to other banks. The ultimate conclusion of the research study has enabled the Lloyd Bank to chalk out a new plan of action and strategy for retaining customers and addressing their diversified grievances pertaining to multi facets of the bank's operations.

Motley (1994) described the process of customer satisfaction as revamping the various strategies being adopted by the bank starting from the restructuring of service provision to the clientele and ending up with the mark improvement in the satisfaction level of the customer.

White (1994) has highlighted the same idea and concluded that telephone banking could become a key aspect of customer satisfaction. The technological advancement has also played an important role in contributing towards the cause of customer satisfaction.

In Pakistan, the users of automated teller machines, telephone banking, on-line banking, e-banking, credit and debit cards, all have played a significant part in uplifting the level of customer satisfaction. A paradigm shift has been noted in the banking industry in terms of concentrating on the customer care by the management rather than managing the financial resources of the bank. In the light of the above discussion, it is mandatory for the banks to pursue a strategy and action that could materialize customer satisfaction.

\subsection{Effects on Quality Dimension}

The quality consideration of a product or service can be termed as the solitary attribute responsible for bringing laurels to any organization. Buzzel and Gale (1987) states that even the competitors and rivals possesses lower weight in contention with the quality dimension as for as the performance of any business is concerned. Higher levels of quality bring in its wake growth in business and prosperity.

In the service-oriented industry and businesses like banks, obviously there is direct contact between the user and the provider of services and satisfaction depends on the quality of service delivery system and borrower or users own personal experience. The literature revealed that there is a significant relationship between the satisfaction level of users of banking services and the provision of quality services.

Keiser (1994) has stated that there is concrete evidence for proving the phenomena that higher quality of services eventually enhances the satisfaction level of the clientele and it ultimately results in maintaining the old customers and attracting new ones. 
Mahoney (1994) describes the idea of service quality as having being replaced by service excellence. Masden (1993) further elaborates the phenomena of service excellence as all those measures taken up by the management of an organization aiming at bringing enchantment to the customers and hence this act accelerate the management's expectation of grabbing greater chunk of market share.

Joseph (1996) has rightly identified that the area of 'TQM' which has now been explored everywhere in the world which stipulates full concentration on the continuous quality improvement of the service and products being delivered to the customers.

\subsection{Impact of Employees Oriented Marketing on Customer Satisfaction}

Kotler and Armstrong (1991) suggests that employees of an organization can become brand ambassadors of the product and services they produced or delivered if they are provided with proper inducements like perks and financial emoluments, encouragement with the word of mouth, and active interaction or involving them in the decision making process pertaining to the organization.

All these measures tend to motivate employees for higher productivity and eventually resulting in amelioration of services and further uplift of the good name and reputation of the firm.

As both Islamic and Conventional banks are service oriented organizations, the impact of employee's role on the quality dimension is well conceived and recorded by the respective management boards of the banks.

Chitwood (1996) opines that the employees plays vital role in bringing satisfaction to the customers and this activity carries heavy weight as the customers are suppose to have direct interaction with the other customers and prospective clientele. The concept of internal marketing in terms of satisfied employees will deliver best services to the clientele has widely been used in the arena of banking business.

Now there is a perceived understanding in the market that the outside clientele will get the best services provided that the internal employees are well satisfied from environment and incentives. Gremler (1995) describes the internal satisfaction to be an index to the ultimate consumers of banking industry. Improvement in the skills and approach of employees is only possible when they get equitable and fair chances for training and development.

\subsection{Benchmark for Bank Selection}

The past three decades has shown tremendous volume of literature on the topic of how to select a bank and its allied avenues. The literature on the topic revealed that majority of the researchers like Haron (1994) and Ross (1989) have used the research tools of questionnaire, a methodology pursued to analyze and evaluate the selection profile. This profile analysis plays a very important role in the selection proceedings.

These characteristics encompasses access to credit and its availability, religious inclination and background, suggestion from friends and relatives, easy and fair approach to banks in terms of their location, diversified banking services, quality considerations, access to modern equipment like ATM, money transfer facility, banking shifts, profitability aspects, behaviour of the staff, comprehension of financial requirements and the general perception of the name and reputation of Islamic and Conventional bank. All those specific areas of the banking world will differ and will be subjected to certain conditions.

Many characteristics which includes the nature of banking in terms of interest bearing conventional banking or interest free Islamic banking, the profile of clients, in terms of their age, qualification, income, religion, professional background and temperament etc.

As there is a mark line of demarcation and distinction between Islamic banking system and Conventional banking system, there is a strong expectation that the profile analysis of the clientele of both the banking systems will signify diverse selection characteristics.

In Islamic banking system those attributes may play a role which will be totally different from the profile of the clientele of Conventional banking system. Hegazy (1995) has made an attempt to study the selection criteria of Islamic banking system and Conventional banking system.

His study revealed that the selection characteristics of Islamic banking system are quite different from that of Conventional banking system. From the Islamic banking perspective, Hegazy argued that the strongest point was noted to be the religious inclination and background of the subscribers and users of Islamic banking products and services. All other attributes were found to be having less importance from the clients' perspective and they were rather very much enthusiastic about the religious satisfaction and were clearly showing ill feelings about the traditional or Conventional banking system. 
In the light of the information received from the subscribers of Islamic banking, the bank authorities, policy makers will have to evolve a marketing strategy to focus on the marked attribute of religious inclination of the subscribers of Islamic banks. The policy makers are expected to materialize the opportunity on the notion of this comparative advantage in alignment with the profile analysis of the customers of Islamic banking system emerging from this survey.

\section{The methodology}

\subsection{The Study Population}

The population of this study consisted of the 942 subscribers and users of Islamic banking products/system.

The methodology employed in this study include: the procedure for data collection, the study sample, the procedure and techniques used in the data analysis and the study limitations. A brief description of each of these elements is presented in this section.

\subsection{The Procedure of Data Analysis}

Two types of analysis were conducted in this study: profile analysis and statistical analysis. Profile analysis can be viewed as a means of classifying a particular set of subjects according to a particular number of relevant attributes. This method is widely used in social science research especially those studies that involve the investigation of behavioral issues. This method of analysis has been used in many studies as a first step before conducting any statistical analysis. The profile analysis employed in this study was conducted via the use of percentages, mean scores and ranks. The results of the analysis are presented in the tables in this study.

In addition to the profile analysis, a non-parametric statistical test was also employed in this study. The selected chi-square test which has been widely used in the literature was adopted in this study for two reasons: first, its suitability to the nature of the data collected, as most of the data are nominal type; second, the application of the technique does not require those restrictive assumptions that are normally associated with most parametric statistical tests. The non-parametric chi-square test has the advantage of not having to apply a particular functional form as with the parametric models, however, the demerit is that it doesn't measure any error term (Farell, 1957)

The value of the test-statistic is:

$$
X^{2}=\sum_{i=1}^{n} \frac{\left(O_{i}-E_{i}\right)^{2}}{E_{i}}
$$

where

$X^{2}=$ the test statistic that asymptotically approaches a $\chi^{2}$ distribution.

$O_{i}=$ an observed frequency;

$E_{i}=$ an expected (theoretical) frequency,

$n=$ the number of possible outcomes of each event.

The chi-square statistic can then be used to calculate a p-value by comparing the value of the statistic to a chi-square distribution. The number of degrees of freedom is equal to the number of cells $n$, minus the reduction in degrees of freedom, $p$.

\subsection{Study Limitations}

There are three main limitations to this research.

First, there were only four Islamic bank branches whose customers participated in this study. Secondly, all the banks have been selected from the area of Peshawar, Pukhtunkhwa. Third limitation concerns the nature of the measures used. The measures included in this research were all based upon the perceptions of the participating customers. Therefore, the potential for data inaccuracies due to item misinterpretation or predisposition to certain responses on the part of the participant does exist. As a result, the generalization of the findings of this research should be considered carefully.

\subsection{Sampling of the Study}

A list of attributes and characteristics of the clientele having access to credit was developed from the current literature to augment the process of identifying and selecting subscribers of Islamic banks for the study. The potential Islamic banks were nominated by the panel of proficient academicians. The four banks having the 
highest number of attributes and characteristics observed during the visits were selected for the purpose of this study.

\section{Sample Size $=100$ subscribers of Islamic banking system.}

Stratified Random Sampling has been used during the proceedings of this study.

Questionnaire based on simple regression have been used for data collection.

\section{Conclusion}

One of the salient points in establishing and incorporating successful business plans and strategies is the maintenance of a detailed analytical profile status of the clientele being kept by the bank and is updated in the light of the current business and economic changes in any country.

When the bank management is fully aware of the customer profile, better type of product and services could be launched in consonance with the peculiar needs of the clientele.

Tables - 1 contains the attributes of the customers of Islamic banking system in terms of their ages classification, educational level attained and monthly income earned.

The results portrayed in table- 1 amply demonstrates that the subscribers and users of Islamic banking products and services are well educated with $41 \%$ secondary school certificate class, $47 \%$ having graduate degrees and above credentials. The result shows that Islamic banking practices are quite popular among the educated class of population in Peshawar and they are induced towards this new system of banking.

Table-1 also highlight that $67 \%$ of the Islamic bank subscribers and users are earning less than Rs. 20000 a month, which is surely a handsome magnitude of the total clientele. The authorities and policy makers of Islamic banking should evolve a dynamic strategy to design and develop innovative products and services in alignment with the Sharia guidelines for this major chunk of population.

Table-1 also shows the all important area of age classification of Islamic bank customers. The result shows that $82 \%$ of the respondents of Islamic banking products and services fall in the age group of 25-50. It clearly demonstrates that the matured and well aware class of the society has a clear inclination towards the Islamic banking. As this age group clientele are in the prime phase of their lives, the policy makers should endeavor to enhance and strengthen interaction with the customers of the said age group.

\subsection{Track Record of Islamic Bank Customers}

Tables-2 shows the track record of the Islamic banking customers in terms of a historical perspective of the banking relationship. Table-2 portrays that $90 \%$ of the respondents of Islamic banking system have had prior interaction with the Conventional banking system before their present status of being an active user of Islamic banking products and services.

The data also shows that only $10 \%$ of the clientele of Islamic banking system were having no relationship with the Conventional banking system previously. While there is a strong possibility that the respondents might have had a clear conceptual framework about Islamic banking system but on the contrary it is expected that their prior banking interaction will exert an influence in terms of their perception and attitudes along with satisfaction level with the existing products being launched by Islamic banks.

The data of table- 2 shows that $54 \%$ of the respondents have kept their linkage with Islamic banks for more than 3 years, $25 \%$ of the respondents have maintained their banking relationship for more than 1 year and $21 \%$ of the surveyed customers have kept their interaction with Islamic banking for less than a year.

The result in table-2 amply demonstrates that Islamic banking has got the attribute of endurance in terms of retaining the clientele. Relatively a higher degree of stability has been found in clients of Islamic banking. The results conclude that the policy makers of Islamic banking will find it beneficial to undergo in-depth analysis of customers' behavior, attitude and satisfaction level.

The appropriate inferences related with table-2 suggests that keeping in view the relatively high level of endurance and permanence in the customer base of Islamic banking, the regulators and policy makers should introduce longer term capital intensive financing schemes and pursue aggressive advertising campaigns to materialize the objective of corporate value creation and growth.

It was noted during this study, that a huge number of business personnel are not using the Conventional banking system for the simple reason that it is interest oriented and this system is absolutely forbidden in the Holy Quran and termed as 'proclaiming war against Allah and His messenger (P.B.U.H). 
Majority of those people are using the parallel banking of 'Hundi' and 'Havala' and other risky mode of private ventures.

\subsection{Familiarity and Orientation with the Major Islamic Banking Products and Services}

Table-3 exhibits the empirical results of the Islamic banks subscribers' familiarity with different products and services and their respective usage. Table- 3 shows that there is a clear dominance of the three basic Islamic banking schemes, Mudaraba, Murabaha and Musharika oriented modes of investment and financing.

The empirical results shown in table- 3 exhibits that a handsome number of Islamic banking customers which constitute $40 \%$ of the total, were found to be unaware of the Islamic banking financing schemes which is an alarming situation. The policy makers and regulators of Islamic banking should evolve an advertising strategy to orient the clientele about Islamic financing schemes and bring them closer to the net of innovative Islamic banking and financing products for eventual progress and growth of Islamic banking industry in Peshawar.

Efforts should also be made to close the gap between those Islamic bank customers who knows about the different modes of financing but are not practically using them at the moment. In the present study, this gap is recorded at $29 \%$ in Mudaraba oriented accounts (Familiarity $89 \%$ and Usage $60 \%$ ), $28 \%$ in Murabaha oriented accounts (Familiarity $99 \%$ and Usage $71 \%$ ) and $47 \%$ in Musharika oriented accounts (Familiarity $62 \%$ and Usage $15 \%$ ).

The results in table-3 also show that majority of the Islamic banking customers are not acquainted to the Islamic banking products of Money Order/Drafts facility and offering of traveling cheques. The percentage recorded for orientation was found to be just $25 \%$ but the situation gets further worsened when the usage score comes down to just $10 \%$. Keeping in view the tremendous number of people traveling from Peshawar to foreign countries like Middle East, China, Japan and Europe in connection with their respective business commitments, these percentage scores demonstrates quite a gloomy picture and there is an enormous potential in this area of operations for the management and policy makers of Islamic banks to focus and concentrate on this area for bringing refinement in the situation.

It was also noted during the course of this study that a mushroom growth of money exchange and 'Havala' companies in Peshawar has emerged during the last 10 years and majority of them operates on illegal terms in the area of Chowk Yadgar Peshawar. These illegal exchange and Havala companies charge the customers at a low rate for money transfer in comparison with commercial banks that's why majority of the money exchange business is tapped by these informal channels.

The products and services like Letter of Credit facility and Bank statements have also received low percentage score of familiarity and usage. These results, however, are in alignments with the facts that the above products and services are not frequently being used elsewhere in Conventional banks also.

In ultimate conclusion, table- 4 shows that the familiarity and orientation level is far below the usage level in most of the products and services being offered by Islamic banks in Peshawar. The results exhibits that the percentage of clients well aware of top ranked products and services like Current accounts, Savings accounts and Fixed Deposit accounts is very high and the percentage recorded was found to be $100 \%, 95 \%$ and $90 \%$ respectively for the said accounts.

The degree of usage of the same products and services were however, somehow quite low in comparison with its awareness. Table- 4 shows a gap of $40 \%$ between the users of Current account holders and those who were oriented to Current accounts. Similarly there is vast gap of $53 \%$ in interest bearing Savings accounts holders in terms of its awareness and usage. This gap further deepens when it comes to the proceedings of Fixed Deposit accounts which are $59 \%$.

The percentage recorded for the acquaintance of customers with financing facilities, ATM and Money Orders/Drafts, Letter of Credit was measured to be $66 \%, 62 \%, 60 \%$ and $80 \%$ respectively. However, their usage was recorded to be just $28 \%, 33 \%, 41 \%$ and $30 \%$ respectively which is quite low score in comparison with the Islamic banking products scores.

The gap between familiarity and usage for the provision of Bank Statements was found to be $45 \%$ which obviously exhibits a huge gap. Just $50 \%$ of the surveyed customers were found to have been acquainted with the monthly income scheme, however just $10 \%$ of the subscribers were actually in practical use of monthly income scheme. The reason behind this state of affair was found to be the fixed interest bearing attribute of these monthly income schemes with which majority of the customers have shown resentment. 


\subsection{Interrelationship between Diversified Social Factors and the Degree of Usage of Major Islamic Banking Products and Services}

To further ameliorate the above mentioned data and extract useful inferences, a number of chi-square tests were conducted to analyze the interrelationship between the major diversified social factors like age, income and education and the usage of Islamic and Conventional banking products and services.

Table-4 exhibits the empirical results of the study.

A significant relationship has been reported by table- 4 about the age group of the customer and the Current account usage. An in-depth analysis of the customer responses showed that the Current account is very much popular among the elderly aged clientele of Islamic banks.

The age groups 35-50 and above 50 were the most common users of Current accounts of Islamic banks. $75 \%$ of the users in those two age groups claimed that they prefer to use Current account being kept with the Islamic banks. The responses of elderly aged groups revealed that Current account is often used by matured customers for trading and business oriented transactions and also for safe keeping of their cash reserves. On the other hand, the group comprising customers of below 25 years of age are using the Current account while $65 \%$ of them were inclined towards other Islamic banking modes of financing and products.

Table-4 also highlight the chi square results which exhibits that the inter relationship between customer ages and other products and services have no observed patterns in this study. The findings of the study revealed that popular modes of financing like Mudaraba, Murabaha are frequently used by the Islamic banking customers irrespective of the diverse age groups. These modes are popular across the board in Islamic banking customers.

A significant relationship has been found between the education level and usage of Murabaha and Mudaraba financing. This fact is evident from significant chi square values of 13.50 for Murabaha and $11.11 \%$ for Mudaraba financing. Furthermore the high frequency distribution for Murabaha and Mudaraba financing shows that the high educated clientele like these modes very much and they enjoys high popularity among the educated clientele. The regulators and policy makers of Islamic banking will find useful information for devising and formulating diversified strategies for product advertising and promotion and specifically the selection of appropriate media mode.

\subsection{The Interrelationship of Clientele of Islamic Banking with the Degree of Familiarity with Banking Products}

Table-3 shows the statistical results of chi square tests of independence conducted on the data collected from the respondents of the Islamic banks. According to the results there was a strong relationship between familiarity about the availability of diverse Islamic bank products and the period of Islamic bank clientele. The results clearly shows that the greater the period of clientage in the Islamic banking arena tends to generate greater orientation and awareness of diversified banking services being launched by Islamic banks.

The results suggests that the regulators and management of Islamic banks should strive to evolve marketing strategies in terms of advertising and promotional campaign for the uplift of Islamic banking products and services aiming at disseminating useful information to the customers. These promotional activities, if planned and executed properly will foster the pace of public orientation about the products and services of Islamic banking system in Peshawar. Hence the usage of Islamic banking products can be accelerated and the hidden potential could be materialized accordingly.

The steps for bringing corrective actions may include avenues like minimizing the cost of operations, making the proceedings subscriber friendly and provision of the state of the art financing and infra-structure banking facilities. Moreover, in-depth and exhaustive studies need to be undertaken to probe the genuine reasons responsible for the gradual decline in the volume of business and profitability for the Conventional banks.

On the other hand, however, the high scores of 3.74 and 3.79 for users of Current Account facilities and ATM users respectively shows the high satisfaction level recorded for both the modes. The Conventional bank seems to have concentrated on these two modes and their performance is up to the mark.

\subsection{The State of Client Satisfaction Level with the Products And Services of Islamic Banking}

The concept of modern marketing strategies and procedures have got pivotal role in today's dynamic environment of modern business. So it is imperative for the operators and management of Islamic banking to evaluate and analyze the implications of marketing concept in alignment with their peculiar needs and objectives.

All the Islamic banking activities should be structured on customer-focused angle and the client's specific needs and requirements should be catered first in order to flourish the broader idea of Islamic banking expansion and 
growth in Peshawar in specific and in Pakistan in general. To arrive at this goal, it is mandatory on the part of the operators and management of Islamic banking to undergo rigorous research process and obtain inferences in terms of analyzing the client's satisfaction level about the various Islamic banking products and services.

Table- 5 shows the conclusions drawn in terms of the degree of satisfaction of the Islamic bank customers about ten different Islamic bank products and services offered to them at Peshawar. Here it's necessary to mention that the customers' satisfaction level is subjected to the condition of mandatory usage by the clients of Islamic banks.

Table-5 exhibits the statistical results of different products and services of Islamic banking along with its respective ranks. On the basis of usage rates of the respondents of Islamic banking reported earlier and the mean satisfaction scores presented in table-5, it is concluded that the Islamic banks customers have shown their sense of satisfaction on the various avenues they encountered mostly while dealing with Islamic banks.

The financing facilities of Islamic banking have received a high mean satisfaction score of 4.83 and it demonstrates that the clientele of the Islamic bank are happy with this mode of Islamic banking.

Another important point was noted about the concern of Islamic bank customers for the cost and flexibility of the said financing schemes. The management of Islamic banks should look into the matter and the cost and flexibility should be rationalized in accordance with the aspirations of the customers of Islamic banks in Peshawar.

The draft facility and traveller cheques facility of Islamic banks showed low satisfaction mean scores. Drafts and Money orders received 1.79 score while 1.70 was the satisfaction score of travellers cheques. One of the reasons for this low scale is the law and order situation in Peshawar which is a main cause of tourists halt into the beautiful valleys of the province which eventually has lead to the meager use of travellers' cheques.

In the light of the results being reported in table-7 which amply exhibits the low customer satisfaction level of Islamic bank clients for major products and services. The management and operators of Islamic banks must take solid steps to enhance the level of refinement and efficacy of products.

These concrete steps may encompass reducing the operational costs, rationalizing and simplifying the procedures for access to credit in diversified avenues, imparting professional training and development schemes to the employees of Islamic banks and further strengthening the Research and Development section of Islamic banks to ameliorate the process of information collection and identifying the loopholes in the system and taking the necessary corrective action accordingly.

The customer satisfaction score for the Islamic bank employees was recorded at 4.08 which is quite handsome score. The customers of Islamic banks spoke very high about the self-motivated personnel and the employees were ranked high by the customers in terms of their excellent performance and good manners and professionalism.

Table- 5 shows the induction procedures being employed by the Islamic bank authorities is very fine and the long term commitment of Islamic banking authorities to induct excellent level of qualified human resources has been amply proved through the results so obtained.

The conducive environment, commitment of employees and religious atmosphere being prevalent at the Islamic bank branches is the result of the broader policy of Islamic bank's management on the issue to emphasize the trustworthy relationship for flourishing the good religious values and expansion of the Islamic banking philosophy to every nook and corner of the country.

Table-6 exhibits the statistical results of the tests on the responses received from the Islamic bank respondents of the study.

The results clearly show that the relationship between the age of clientele and religious inclination as a selection choice of Islamic banking products and services has got a significant relationship. The chi-square value of 89.1 is shown at table- 20 which is significant at 0.00 levels. An in-depth analysis of Islamic banking customers revealed that in the age group $25-35,84 \%$ of them were of the view that the religious regulations and principles plays a dominant role in the bank system selection decisions. It shows that the comparatively younger generation of Peshawar are religiously inclined and act upon the teachings of Islam. On the other hand, the age group 35-50, which is a matured level of respondents, shows that $56 \%$ of them consider Islamic teachings to be indispensable.

Taking conclusion from the above state of affairs, it is recommended that the Islamic banking operators and management should strive to introduce products and services which conform to the aspirations of the new generation. The management and operators are advised to materialize the opportunity by conducting seminars 
about Islamic banking system and its allied avenues in Universities, colleges, Chamber of Commerce and government offices. The potential in terms of provision of capital goods like houses, automobiles, equipment and other durable goods for the younger generation is enormous and banks can devise good strategies to take full advantage of the rapid growing market.

As for as the linkage in academic qualification of the respondents and the degree of importance of selection criteria of banks is concerned, the results shows quite significance in the educational level and the degree of religious regulations in the selection of banks. The examination of the results revealed that those respondents having graduate degrees in diverse avenues are more influenced from the Islamic teachings and principles in selecting bank in comparison with other respondents having other academic qualification. The results also show that the less educated respondents are comparatively more influenced form friends and family. This fact is demonstrated by the significant chi-square value of 31.59 .

In the final analysis, the chi-square valued of 24.4 indicates a very strong linkage in academic education of the respondents and the degree of relative convenient location of Islamic banks.

Further analysis showed that the less educated respondents and customers of Islamic banking have a less concentration on access to the bank premises as a characteristic in comparison with highly educated customers who tends to put more emphasis on the same.

The empirical results suggest that the regulators of the Islamic banking should concentrate on the demography of a location when it comes to establishment of a new branch. Branches should be opened at those places where the prospective clientele are well-educated and inclined towards the Islamic principles in order to tap this untapped market. The aspirations and preferences of the educated class shall be taken into consideration and products and services should be designed in such a way to cater to the needs of the subscribers.

The study results confirm the relative importance of the location of an Islamic bank's selection criteria.

\section{References}

Bartell, S. (1993). Building strong customer relations. Bank Marketing, Vol. 25 No.6, pp.16-19.

Bedall, D., \& Power, T. (1995). Cultivating loyal patients. Journal of Health Care Marketing, Vol. 15 No.4.

Buzzel, R.D., \& Gale, B.T. (1987). The PIMS Principles: Linking Strategy to Performance. Free Press, New York, NY.

Chitwood. (1994). Public Religions in the Modern World. Chicago: University of Chicago Press, 1994.

Dispensa. (2005). The Islamic Business Enterprise. Croom Helm, London.

Farrell, M.J. (1957). The measurement of productive efficiency. Journal of the Royal Statistical Society, 120 (3): 253-281.

Gremler, D., Bitner, M., \& Evans, K. (1995). The internal service encounter. Logistics Information Management, Vol. 8 No.4, pp.28-34.

Gulledge, C. (1982). Strategic Management and Marketing in the Service Sector. Swedish School of Economics and Business Administration, Helsinfors.

Haron, S., Ahmed, N., \& Planisek, S. (1994). Bank patronage factors of Muslims and non-Muslim customers. International Journal of Bank Marketing, Vol. 12 No.1, pp.32-40.

Hegazy, I.A. (1995). An empirical comparative study between Islamic and commercial banks' selection criteria in Egypt. International Journal of Contemporary Management, Vol. 5 No.3, pp.46-61.

Joseph, W.B. (1996). Internal marketing builds services quality. Journal of Health Care Marketing, Vol. 16 No.1, Karsten, I., 1982.

Keiser, R. (1992). A light in Asia Pacific (Part II). Bank Systems and Technology, Vol. 29 No.3, pp.36-44.

Kotler, P., \& Armstrong, G. (1991). Principles of Marketing, 5th ed., Prentice-Hall, Englewood Cliffs, NJ.

Mahoney, L. (1994). Service quality/service excellence. Bank Marketing, Vol. 26 No.4, pp.66.

Masden, G. (1993). Service excellence: a step beyond quality. Bank Marketing, Vol. 25 No.10, pp.39-41.

Motley, L.B. (1994). The one-toe punch in marketing strategy. Bank Marketing, Vol. 26 No.5, pp.80.

Rosa, D.A. (1986). Islamic financial policies and domestic resource mobilization. Savings and Development, 2:143-53. 
Solomon, M. (1996). Consumer Behavior, 2nd ed., Allyn \& Bacon, Boston, MA, pp.346.

Vavra, (1990). Eastern Asian Enterprise Structure and the Comparative Analysis, Forms of Business Organization. Organization Studies.

Waterhouse, K., \& Morgan, A. (1994). Using research to help keep good customers: understanding the process of customer defection and developing a strategy for customer retention!. Marketing and Research Today, Vol. 22, No.3, pp.181-94.

White, D. (1994). Familiarity breeds content. Banking World, Vol. 12 No.5, p.18

Table 1. Salient attributes of Islamic bank customers

\begin{tabular}{|c|c|}
\hline & Percentage \\
\hline \multicolumn{2}{|c|}{ AGE } \\
\hline Less than 25 years & 10 \\
\hline $25-40$ years & 52 \\
\hline $41-50$ years & 30 \\
\hline Above 50 years & 08 \\
\hline \multicolumn{2}{|c|}{ EDUCATION } \\
\hline Under Secondary School & 12 \\
\hline Secondary School Certificate & 41 \\
\hline Graduate & 37 \\
\hline Master Degree & 10 \\
\hline \multicolumn{2}{|c|}{ INCOME } \\
\hline Less than Rs. 10000 & 10 \\
\hline Rs.10000-15000 & 32 \\
\hline Rs. $15001-20000$ & 25 \\
\hline Rs. 20001-25000 & 10 \\
\hline Rs. 25001-30000 & 08 \\
\hline More than Rs.30000 & 15 \\
\hline
\end{tabular}

Source: Survey conducted by the researcher

Table 2. Track record of banking relationship of Islamic bank subscribers

\begin{tabular}{|l|l|c|}
\hline Group & Profile & Percent \\
\hline A & Prior interaction with Conventional banks & \\
\hline & Yes & 90 \\
\hline & No & 10 \\
\hline B & Period of interaction with Islamic banks & \\
\hline & Less than 1 year & 25 \\
\hline & $1-3$ Years & 21 \\
\hline & 3 Years and More & 54 \\
\hline
\end{tabular}

Source: Survey conducted by the researcher

Table 3. Familiarity and orientation with major Islamic banking products/services

\begin{tabular}{|l|l|c|c|}
\hline Sr. No & \multicolumn{1}{|c|}{ Type of Product/service } & \% Familiarity & \% usage \\
\hline 1 & Mudaraba Oriented Accounts & 89 & 60 \\
\hline 2 & Murabaha Oriented Accounts & 99 & 71 \\
\hline 3 & Musharika Oriented Accounts & 62 & 15 \\
\hline 4 & Financing Oriented Facilities & 61 & 31 \\
\hline 5 & Investment Modes/Accounts & 92 & 80 \\
\hline 6 & Current Accounts & 84 & 69 \\
\hline 7 & Drafts/Money Orders & 25 & 10 \\
\hline 8 & ATM & 80 & 34 \\
\hline 9 & Letter of Credits & 30 & 10 \\
\hline 10 & Bank Statements & 30 & 05 \\
\hline
\end{tabular}

Source: Survey conducted by the researcher 
Table 4. The inter-relationship between diversified social factors and the degree of usage of majors Islamic bank products/services

\begin{tabular}{|l|c|c|c|c|c|c|c|c|c|c|c|}
\hline $\begin{array}{l}\text { Diversified } \\
\text { Social factors }\end{array}$ & $\begin{array}{c}\text { Mudaraba } \\
\text { Financing }\end{array}$ & $\begin{array}{c}\text { Murabaha } \\
\text { Financing }\end{array}$ & $\begin{array}{c}\text { Musharika } \\
\text { Financing }\end{array}$ & $\begin{array}{c}\text { Current } \\
\text { Account }\end{array}$ & $\begin{array}{c}\text { Investment } \\
\text { Accounts }\end{array}$ & $\begin{array}{c}\text { Financing } \\
\text { Facilities }\end{array}$ & ATM & LC & $\begin{array}{c}\text { Bank } \\
\text { Statements }\end{array}$ & $\begin{array}{c}\text { Money } \\
\text { Orders }\end{array}$ \\
\hline \multicolumn{7}{|c|}{ Age } \\
\hline X2 & 14.81 & 2.44 & 7.44 & 9.09 & 1.86 & 3.79 & 3.0 & 4.56 & 1.27 & 3.191 \\
\hline DF & 3 & 3 & 3 & 3 & 3 & 3 & 3 & 3 & 3 & 3 \\
\hline P & 0.005 & 0.655 & 0.11 & 0.05 & 0.77 & 0.43 & 0.55 & 0.33 & 0.86 & 0.363 \\
\hline
\end{tabular}

Source: Survey conducted by the researcher

Table 5. Score of customers' satisfaction level with the major Islamic banking products/services

\begin{tabular}{|l|c|c|}
\hline \multicolumn{1}{|c|}{ Type of Product/service } & Degree of Mean Score & Satisfaction Rank \\
\hline Murabaha Financing & 3.30 & 4 \\
\hline Mudaraba Financing & 3.76 & 2 \\
\hline Musharika Financing & 1.70 & 6 \\
\hline Savings Accounts & 3.79 & 1 \\
\hline Current Accounts & 1.83 & 5 \\
\hline Investment Accounts & 3.60 & 3 \\
\hline
\end{tabular}

Source: Survey conducted by the researcher

Table 6. Islamic banking customers satisfaction score about the delivery system

\begin{tabular}{|l|c|c|}
\hline \multicolumn{1}{|c|}{ Elements of product/service delivery system } & Degree of Satisfaction & Rank \\
\hline Professional conduct of Bank Employees & 4.08 & 1 \\
\hline Facilities and Equipment & 3.28 & 4 \\
\hline Convenient Location & 3.48 & 2 \\
\hline Night Banking & 3.87 & 3 \\
\hline
\end{tabular}

Source: Survey conducted by the researcher

Table 7. Factors leading to the customer's choice for selection of Islamic banking products/services

\begin{tabular}{|l|c|c|}
\hline \multicolumn{1}{|c|}{ Factor } & Degree of Importance & Rank \\
\hline Religious Inclination & 4.7 & 1 \\
\hline Family and Friends & 3.89 & 2 \\
\hline Easy access to branch & 3.00 & 4 \\
\hline Profitability & 3.85 & 3 \\
\hline
\end{tabular}

Source: Survey conducted by the researcher 
Table 8. The inter-relationship between diversified social factors and the factors leading to customer's choice of Islamic banking products/services

\begin{tabular}{|c|c|c|c|c|}
\hline \multicolumn{5}{|c|}{ SELECTION CRITERIA } \\
\hline Diverse Social factors & Religious Inclination & Family and Friends & Easy Access to branch & Profitability \\
\hline \multicolumn{5}{|l|}{ AGE } \\
\hline $\mathrm{X} 2$ & 89.1 & 32.82 & 26.92 & 11.19 \\
\hline DF & 12 & 12 & 12 & 12 \\
\hline $\mathrm{P}$ & 0.00 & 0.08 & 0.13 & 0.512 \\
\hline \multicolumn{5}{|l|}{ INCOME } \\
\hline $\mathrm{X} 2$ & 75.27 & 31.58 & 24.79 & 10.67 \\
\hline DF & 20 & 20 & 20 & 20 \\
\hline $\mathrm{P}$ & 0.000 & 0.10 & 0.15 & 0.10 \\
\hline \multicolumn{5}{|l|}{ EDUCATION } \\
\hline $\mathrm{X} 2$ & 75 & 31.59 & 24.4 & 10.67 \\
\hline DF & 16 & 16 & 16 & 16 \\
\hline $\mathrm{P}$ & 0.001 & 0.05 & 0.10 & 0.557 \\
\hline
\end{tabular}

Source: Survey conducted by the researcher 